\title{
To Know Paul Corey: An Introduction
}

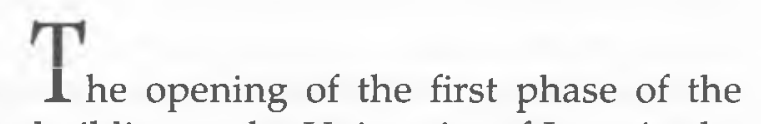

present Main Library building at the University of Iowa in the early 1950s was marked by an unusual display of books and manuscripts written by former students. Among these was the manuscript of Paul Corey's Three Miles Square, the first volume of his "Mantz trilogy," recounting life on a western-lowa farm during the opening decades of this century. A graduate student at the time, I was not familiar with Corey's work, and I surely did not know that by that time he had pretty well abandoned fiction and gone on to other kinds of writing (books about cats, for one). In any event, it was some years before I came across his name again.

That happened in South Dakota, in 1986. At the State Archives I happened upon the letters written by Paul's sister Elizabeth during the years 1909-19 when she had homesteaded a claim in the valley of the Bad River. Paul, as it turned out, had deposited those letters, which were family keepsakes. Tasting of them, I knew at once that I wanted to edit them. To do so meant that, if humanly possible, I must find Paul Corey.

By good fortune, I did locate Paul and found, not only that indeed he lived, but that at age eighty-three he was active and alert. More serendipity: he was eager to assist me in editing Bess's letters for publication. That fall I was on an "exchange professorship" at the University of Delaware, and Paul kindly mailed me the typescript he had made of the letters many years before. Reading it convinced me that I would need to work as closely as possible with Paul. Considering his age, I must start the process as soon as could be managed.

As luck would have it, I was to begin a sabbatical leave from SUNY in January 1987. Traveling to California, where Paul had 
lived since 1947, my wife, Gene, and I soon found ourselves driving through a wild, wooded tract, up a very narrow, very steep, and very winding trail called Cavedale Road just north of Sonoma. Here, in a home he had built with his own hands (and then written a book about it), Paul lived with his wife, the poet Ruth Lechlitner. We spent a number of days in Sonoma, picking Paul's brain, planning our book of letters, and dipping into the Corey files for family papers, photographs, genealogical records, anything that might help to flesh out the sometimes bare-bones references Bess was given to making about friends and events that now were in the distant past. On a daily basis we were re-introduced to Ruth, then in advanced stages of Alzheimer's disease. Paul's devoted attention to her was something to behold, we thought, a lesson in infinite patience.

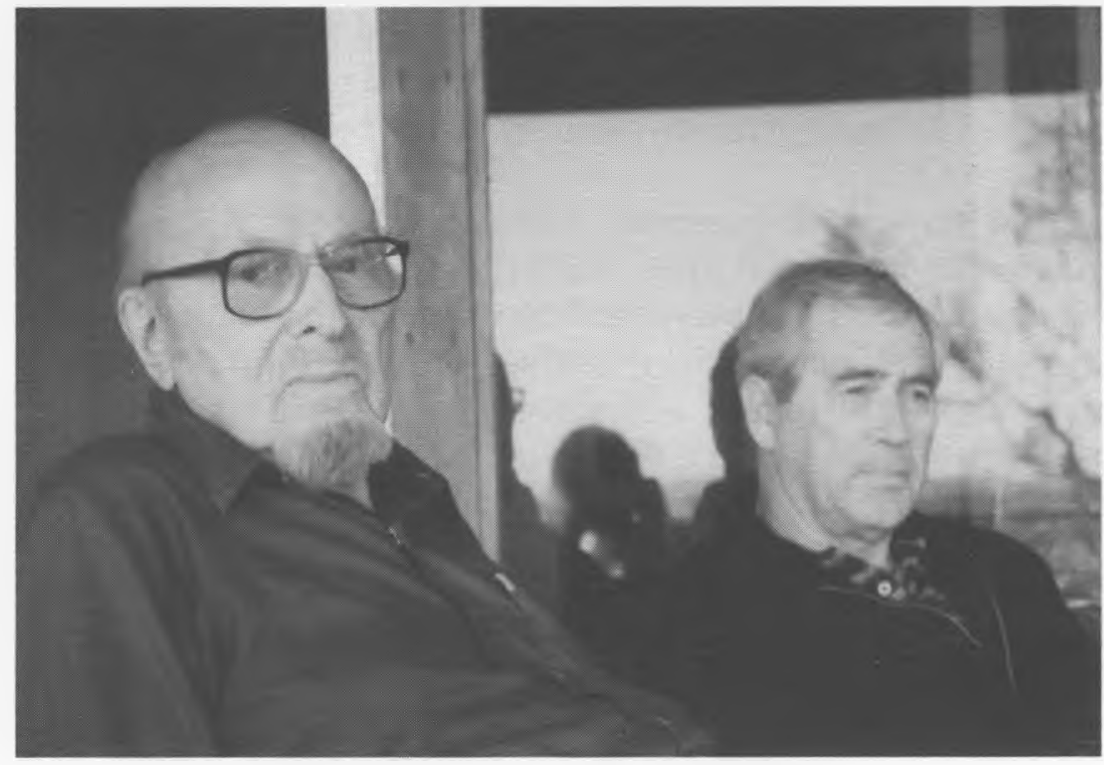

Paul Corey (left) with Philip Gerber in Sonoma, 1987

Over the next three years Paul and I corresponded regularly. I had a thousand questions about Bess's references to the farm life she had left behind when she launched her western 
adventure. These were relayed to Paul for identification, and his memory proved to be amazingly intact. Whether Bess's references had to do with old friends and neighbors, family members (including the horses and the dogs), or to events of neighborhood life, Paul unlocked his memory to provide the specifics. In the process, he related any number of anecdotes which helped me to comprehend the personalities of his siblings and the roles they had played in his life and that of his homesteading sister.

I took a rich personal pleasure from the fact that Paul lived to see his sister's letters published splendidly by the University of Iowa Press in 1990 under the name that she had selected for herself: Bachelor Bess. Somehow, Bess's letters, which taken altogether went back to 1904, seemed to round out Paul's professional career. Life was a circle, taking him back to his own beginnings.

He impressed us as one of the last great individualists, surely, with an immense belief in making his own way in life, standing on his own two feet, choosing his own path, being beholden to no one. To his last days he remained active in ecological groups in the Sonoma Valley, speaking out firmly whenever he saw the native terrain or fauna under threat. A continent away, our own spirits rose whenever we found one of his blue envelopes in our daily mail.

What a privilege it was to know Paul Corey! And how we miss him! This memorial issue of Books at lowa is an attempt (foredoomed, of course) to communicate something of the flavor of the man, in both his literary and personal dimensions.

Philip Gerber, Guest Editor Summer 1994 